\title{
TOWARD A CRITICAL ENVIRONMENTAL JUSTICE STUDIES
} Black Lives Matter as an Environmental Justice
Challenge

\author{
David N. Pellow \\ Department of Environmental Studies, University of California, Santa Barbara
}

\begin{abstract}
In this paper I expand upon the recent use of the term "Critical Environmental Justice Studies." This concept is meant to capture new developments in Environmental Justice (EJ) Studies that question assumptions and gaps in earlier work in the field. Because this direction in scholarship is still in its formative stages, I take this opportunity to offer some guidance on what Critical Environmental Justice (CEJ) Studies might look like and what it could mean for theorizing the relationship between race (along with multiple additional social categories) and the environment. I do so by (1) adopting a multi-disciplinary approach that draws on several bodies of literature, including critical race theory, political ecology, ecofeminist theory, and anarchist theory, and (2) focusing on the case of Black Lives Matter and the problem of state violence.
\end{abstract}

Keywords: Environmental Justice, Black Lives Matter, State Violence, Racism, Speciesism, Scale, Expendability, Indispensability

\section{INTRODUCTION}

Black Lives Matter (BLM) is a social movement centered on the problem of statesanctioned racist violence. The movement began as a response to the acquittal of George Zimmerman, a man who killed Trayvon Martin, a seventeen-year old African American boy in Sanford, Florida, in 2012. From that moment on, social media, mainstream media, and the Black Lives Matter movement would routinely intensify the national focus on racialized state-sanctioned violence when yet another video or testimony surfaced featuring an African American being shot, beaten, choked, and/or killed by police or White vigilantes. The role of social media technology was pivotal. As one writer put it, "Social media could serve as a source of live, raw information. It could summon people to the streets and coordinate their movements in real time. And it could swiftly push back against spurious media narratives ..." (Bijan 2015).

BLM co-founder Alicia Garza explained what the movement stands for: "Black Lives Matter is an ideological and political intervention in a world where Black lives are systematically and intentionally targeted for demise. It is an affirmation of Black 
folks' contributions to this society, our humanity, and our resilience in the face of deadly oppression" (Garza 2014).

In this paper, I draw links between what I view as the most important insights and questions that emerge from the Black Lives Matter movement and the struggle against environmental racism. This is a connection that many scholars might not make at first glance because police brutality and environmental politics would appear to be only tangentially related, but I argue they are in fact closely intertwined and that we must explore their myriad connections in order to excavate the roots of racist violence no matter the form it takes. The questions I explore here include: How can Black Lives Matter's emphasis on police violence against African American communities inform our understanding of the scourge of ecological burdens facing those same communities? Conversely, what can the violation of Black bodies and spaces by ecologically destructive agents produced by states and corporations tell us about the violation of those same bodies by police and law enforcement agents? I find that a "first-" and "second-generation" Environmental Justice Studies framework can assist in this effort, but can only take us so far. Therefore, I propose that a Critical Environmental Justice Studies framework can more fully address these pressing concerns.

\section{ENVIRONMENTAL JUSTICE STUDIES}

The Environmental Justice (EJ) movement is composed of people from communities of color, indigenous communities, and working-class communities who are focused on combating environmental injustice-the disproportionate burden of environmental harm facing these populations. For the EJ movement, social justice is inseparable from environmental protection.

In the early 1970s, researchers in the United States found strong correlations between social class status and air quality in the United States. As a result of social movement activism, however, the focus began to broaden from social class to race and from air pollution to a range of environmental hazards (Pulido 1996; Walker 2010). For example, in 1982, hundreds of civil rights leaders and community activists protested a toxic waste dump in the majority African American community of Warren County, North Carolina. That action sparked the discourse of environmental racism and the growth of Environmental Justice Studies, and since that time, scholars and other researchers have documented the reach of environmental racism/inequality in the United States and around the globe, as well as the social movement that has emerged to highlight and challenge this phenomenon (Bullard 2000; Cole and Foster, 2000; Pellow and Brulle, 2005).

Thus, hundreds of studies have documented that people of color, people of lower socioeconomic status, indigenous and immigrant populations, and other marginalized communities are disproportionately affected by ecologically harmful infrastructures, such as landfills, mines, incinerators, polluting factories, and destructive transportation systems, as well as by the negative consequences of ecologically harmful practices, such as climate change/disruption and pesticide exposure (Ringquist 2005). Much of this work has documented the troubling depths and breadth of environmental injustice's impact on the lives of people-including public health and mental health effects-and on how these communities make meaning out of these assaults while organizing for environmental justice. And while EJ Studies may have earlier focused on the United States, scholars are also documenting environmental inequalities and EJ movements' responses to them around the globe (Agyeman et al., 2010; Pellow 2007; 
Roberts and Parks, 2006). A small but growing group of researchers-including and especially environmental humanities scholars-have focused on the ways that gender, sexuality, citizenship, indigeneity, and nation shape the terrain of ecological inequalities, but those areas of scholarship remain in need of further development (Adamson 2011; Bell 2013; Buckingham and Kulcur, 2010; Gaard 2004; Smith 2005).

\section{TOWARD A CRITICAL ENVIRONMENTAL JUSTICE STUDIES}

Recent scholarship divides EJ Studies into two phases: (1) the "first-generation," which was focused primarily on documenting environmental inequality through the lens of race and class; and (2) "second-generation" studies that extend beyond questions of distribution to incorporate a deeper consideration of theory and the ways that gender, sexuality, and other categories of difference shape EJ struggles (Buckingham and Kulcur, 2010; Walker 2010). In our book Power, Fustice, and the Environment, Robert Brulle and I used the term "Critical Environmental Justice Studies" (Pellow and Brulle, 2005), which has since been adopted by other scholars working to expand the academic field and politics of environmental justice (Adamson 2011; Holifield et al., 2010). This concept is meant to build on recent scholarship in EJ Studies"second-generation" writings-that questions assumptions and gaps in earlier work in the field by embracing interdisciplinarity and methodologies and epistemologies including and beyond the social sciences. As this direction in scholarship is still in its formative stages, I take this opportunity to offer some guidance for what a Critical EJ Studies might look like.

Critical EJ (CEJ) Studies is a perspective intended to address a number of limitations and tensions within EJ Studies. These include, for example: (1) questions concerning the degree to which scholars should place emphasis on one or more social categories of difference (e.g., race, class, gender, sexuality, species, etc.) versus a focus on multiple forms of inequality; (2) the extent to which scholars studying EJ issues should focus on single-scale versus multi-scalar analyses of the causes, consequences, and possible resolutions of EJ struggles; (3) the degree to which various forms of social inequality and power-including state power-are viewed as entrenched and embedded in society; and (4) the largely unexamined question of the expendability of human and non-human populations facing socioecological threats from states, industries, and other political economic forces.

On the first point above, EJ scholars have a tendency to focus on only one or two forms of social inequality in studies of environmental injustice. For example, some scholars continue to debate the relative importance of race versus class in terms of which category is most important with respect to the distribution of environmental hazards, while only a small group of scholars have explored the role of gender and sexuality in EJ Studies (Buckingham and Kulcur, 2010; Smith 2005). Moreover, the key social category species remains, at best, at the margins of the field of EJ Studies, despite the fact that, generally, when and where humans suffer from environmental inequalities, so does the more-than-human world (and vice versa) and often as a result of ideological frameworks that link marginalized humans to "nature." My point here is that since multiple forms of inequality drive and characterize the experience of environmental injustice, the field would do well to expand in that direction. Thus CEJ Studies brings greater attention to how multiple social categories of difference are entangled in the production of environmental injustice, from race, gender, sexuality, ability, and class to species, which would attend to the 
ways that both the human and the more-than-human world are impacted by and respond to environmental injustice.

With respect to the second point above concerning scale, the EJ Studies literature tends to be characterized by research at one scale or another, rather than a multi-scalar approach. In other words, most researchers focus on the local, regional, national, or sometimes transnational or global scale, but few studies attempt to grasp how EJ struggles function at multiple scales, from the cellular and bodily level to the global level and back (Herod 2011; Sze 2016). Some scholars have addressed this important question by exploring cases in which pollutants produced in one part of the world travel across national borders and impact human and ecological health in another hemisphere (Sze 2006). Scale is of critical importance because it allows us to understand how environmental injustices are facilitated by decision-makers who behave as if sites where hazards are produced "out of sight and out of mind" are somehow irrelevant to the health of people and ecosystems at the original sites of decision-making power and consumption. Attention to scale also assists us in observing how social movement responses to environmental injustices draw on spatial frameworks, networks, and knowledge to make the connections between hazards in one place and harm in another. CEJ Studies thus advocates multi-scalar methodological and theoretical approaches to studying EJ issues in order to better comprehend the complex spatial and temporal causes, consequences, and possible resolutions of EJ struggles.

Regarding the third point above- the degree to which various forms of inequality and power are viewed as entrenched in society-this concern stems from my conclusion that the vision of change articulated by EJ Studies scholars and most EJ activists generally looks to the state and capital to accommodate demands via legislation, institutional reforms, and other policy concessions. The concern here is that such an approach leaves intact the very power structures that produced environmental injustice in the first place. Yes, it names those institutions and structures as sources of the problems and seeks to reform them, but by working in collaboration with those entities, such efforts ultimately risk reinforcing their legitimacy. CEJ Studies urges a deeper grasp of the entrenched and embedded character of social inequality-including speciesism and state power-in society and therefore a reckoning with the need for transformative (rather than primarily reformist) approaches to realize environmental justice. In other words, Critical EJ Studies seeks to push our analyses and actions beyond the human, the state, and capital via a broad anti-authoritarian perspective.

Regarding the fourth point above, EJ Studies suggests that various marginalized human populations are treated-if not viewed — as inferior, and less valuable, to society than others. This point is largely undertheorized in the literature (Mills 2001; Pulido 1996). Critical EJ Studies makes this theme explicit by arguing that these populations are marked for erasure and early death, and that ideological and institutional othering is linked to the more-than-human world as well. Moreover, CEJ counters that dominant perspective with a framework that contends that these threatened bodies, populations, and spaces are indispensable to building socially and environmentally just and resilient futures for us all.

The above constitute what I call the four pillars of CEJ Studies. CEJ Studies draws from the work of scholars across numerous fields that only periodically intersect, such as Environmental Justice Studies (Adamson 2011; Bell 2013; Bullard 2000; Cole and Foster, 2000), Critical Race Theory (Goldberg 2002), Critical Race Feminism (Hong 2006; Smith 2005), Ethnic Studies (Márquez 2014), Gender and Sexuality Studies and Ecofeminism (Buckingham and Kulcur, 2010; Gaard 2004), Political Ecology (Bennett 2009), and Anti-Authoritarian/Anarchist Theory (Scott 2010; Smith 2011). Furthermore, CEJ Studies is interdisciplinary, multi-methodological, and 
is activist-scholar inspired in that it seeks to bridge and blur the boundaries and borders between the academy and community, theory and practice, analysis and action. Critical EJ Studies is only intended to be one of many possible approaches to environmental justice scholarship and action. It is neither prescriptive, nor is it a declaration of where the field should be headed.

In the following sections, I apply a CEJ Studies framework to the Black Lives Matter movement to demonstrate the importance of encouraging scholars and activists to think through linkages across theory and social change politics that might not usually emerge from "traditional" EJ Studies or from within many social change movements.

\section{CRITICAL EJ STUDIES AND BLACK LIVES MATTER}

In order to examine Black Lives Matter as a CEJ case study, I gathered data from the BLM website, archives, and social media, as well as major essays published in national and international media outlets by BLM advocates and supporters. This selection of data is not intended to be strictly representative, but rather, as a purposive sample it speaks to the core BLM frames and the four pillars of CEJ Studies.

\section{The First Pillar: Intersectionality and the Racial Discourse of Animality}

CEJ Studies recognizes that social inequality and oppression in all forms intersect and that members of the more-than-human world are subjects of oppression and agents of social change. Black Lives Matter is a social movement organized primarily around the social category of race, but extends the analysis to multiple categories of difference, reflecting an emphasis on intersectionality. Intersectionality is a concept intended to explain the ways that many identities and social categories work together to produce advantages and disadvantages across bodies and space, and that inequalities do not act independently of one another (Collins 2008; Hong 2006).

The founders of BLM present a deeply intersectional approach to the problem of devalued Black life that is inclusive of class, gender, sexuality, immigration status, citizenship, age, ability, and other differences and social categories. All three founders of BLM are women of color. One of them-Alicia Garza-identifies as a queer woman of color, while another-Opal Tometi-is the daughter of Nigerian immigrants and works for an organization focused on the human rights of Black immigrants. The third founder-Patrisse Cullors-who also identifies as queer, organizes support for incarcerated persons and their families, with a focus on mental health. Thus their political and professional work itself is a study in intersectional theory and practice. As BLM co-founder Alicia Garza writes, "Black Lives Matter affirms the lives of Black queer and trans folks, disabled folks, Black-undocumented folks, folks with records, women, and all Black lives along the gender spectrum" (Garza 2014).

Critical EJ Studies speaks to the ways in which various social categories of difference work to place particular bodies at risk of exclusion, marginalization, erasure, discrimination, violence, and othering. These insights are important for building an understanding of the ways that intra-human inequality and oppressions function and how they intersect with human-nonhuman oppression. As David Nibert and Michael Fox put it, "[T]he oppression of various devalued groups in human societies is not independent and unrelated; rather, the arrangements that lead to various forms of oppression are integrated in such a way that the exploitation of one group frequently augments and compounds the mistreatment of others" (Nibert and Fox, 2002, p. 13). "Various devalued groups in human societies" frequently include women, immigrants, 
LGBTQ persons, people of color, indigenous peoples, disabled persons, the elderly, low-income people, and nonhuman species. And while the experiences of these groups are qualitatively distinct (i.e., not equivalent), the logic of domination and othering as practiced by more powerful groups, the state, and capital provides the common thread of intersectionality through each of their oppressions.

Law enforcement personnel routinely engage in violent acts against humans and nonhumans, even when no threat is evident, thus revealing the ways that state violence produces intersecting oppressions. A 2015 Baltimore Sun investigation of the Baltimore, Maryland Police Department (the same town where Freddie Gray was murdered), detailed numerous incidents in which vulnerable people and nonhumans were the subjects of brutal and sometimes lethal force at the hands of police in that city. The report notes that young African American males were the targets of such violence, and so were elderly people, women, children, and nonhuman animals (Friedersdorf 2015). The report discusses, for example, the use of a dead rat to intimidate a police officer working on a police brutality case and the murder of a dog by an officer to intimidate his girlfriend. The Baltimore Sun investigation appears to reflect what scholarly studies have long revealed: that there is a well-documented link between the use of violence against nonhuman animals and efforts to exert control over other humans, whether in the destruction of livestock and other food sources during wartime and conquests or through domestic violence directed primarily at women, children, and nonhuman companion animals or pets (Adams 2010; Ascione 1997; Smits 1994).

This brings us to what I call the racial discourse of animality, a term meant to capture the language that people use to describe human behavior using nonhuman references and analogies, signaling a set of assumptions surrounding what we view as acceptable "human" versus nonhuman behavior and how different bodies are valued. It reveals the means through which we discuss race, racism, and racial politics in more-than-human terms, as a way of defining the limits and boundaries of the human. This discourse is common in discussions around racial politics and flared up many times around BLM protests against police brutality. What is fascinating is that people on all sides of the issues-activists, lawyers, and agents of the state-use this language. In other words, people deploy the racial discourse of animality in the service of White supremacy and in the service of racial justice. Consider the following examples:

Lesley McSpadden, the mother of Michael Brown (an African American teenager killed by a police officer in Ferguson, Missouri) spoke to reporters at a public demonstration to call attention to the tragedy of her son's death. She spoke to the bleak outlook of young African Americans facing police brutality: "You took my son away from me! You know how hard it was for me to get him to stay in school and graduate? You know how many Black men graduate? Not many! Because you bring them down to this type of level where they feel they don't got nothing to live for anyway!" While other protesters around McSpadden peacefully raised their hands in symbolic surrender, a police officer's voice was heard and recorded yelling at them, calling them "animals" (Fantz et al., 2014).

In early 2015, Freddie Gray, a twenty-five year old African American man was taken into police custody in Baltimore, Maryland, and, in the process, incurred severe spinal cord and neck injuries and died shortly afterward, sparking nationwide protests. In Baltimore, the protests, led by African Americans and many supporters of the BLM movement, were mainly peaceful but were marred by property destruction, looting, and a number of police officers being injured. Many Whites took to social mediaincluding Baltimore County police officer Jennifer Lynne Silver-and displayed their views on the matter referring to the people involved as "animals" and, in her words, a "disgrace to the human race" (Change.org 2015). 
The racial discourse of animality is also used to combat racism. An article in The Guardian responded to Jennifer Silver's epithets regarding protesters in Baltimore by arguing that police and society often treat nonhuman animals better than African Americans:

But 'animals' is a misnomer. People-including police officers-are punished for killing or doing harm to domestic animals. Baltimore has busted dog fighting rings and sent offenders to prison for animal cruelty. In 2014, former Baltimore City police officer Alec Taylor was sentenced to a year behind bars for killing a dog. That might not seem like much, but it is longer than the sentences given to the killers of Michael Brown, Eric Garner, Trayvon Martin, Rekia Boyd, or seven-year old Aiyana Stanley-Jones (Nichols 2015).

In the spring of 2015, a police officer shot Walter Scott, an unarmed African American man in North Charleston, South Carolina, after he fled his car during a traffic stop. Malik Shabazz, president of Black Lawyers for America and former chairman of the New Black Panther Party, appeared on "CNN Newsroom" and stated, "Black men are being killed and hunted down like deer and like dogs" (Griswold 2015). That same month, Democratic Congressman Hank Johnson of Georgia took to the floor of the House of Representatives to urge his colleagues to confront police brutality. Drawing on a phrase usually reserved for hunting nonhuman animals, he stated, "It feels like open season on Black men in America" (Griswold 2015, emphasis added).

In these last examples, references to nonhumans are used to communicate the sentiment that African Americans-like all human beings, presumably-should not be treated like nonhuman animals. The assumption here is also problematic because it is speciesist in that it implies that it is acceptable to wantonly hunt and slaughter nonhumans, even if the primary aim is to counter racist violence. My point is that we cannot understand racist violence, and the way we think, talk, and enact it, without paying attention to the relationship between humans and nonhumans, as these examples illustrate.

Finally, the role of agency is key to the first pillar of CEJ, since African Americans and other marginalized populations are not just the targets of oppression but also regularly resist their subjugation. While traditional elements of what sociologists call "resource mobilization" (Morris 1984) are on full display with the Black Lives Matter movement-including the mobilization of human bodies, ideas, words, discourses, tactics, and strategies in protest - it is also the case that the urban built environment, information technology, and other forms of more-than-human objects and natures are also integral to that agency and therefore central to making this vision and practice of social change possible (Bennett 2009).

\section{The Second Pillar: Scale, Race, and Difference}

CEJ Studies embraces multi-scalar methodological and theoretical approaches in order to better comprehend the complex spatial and temporal causes, consequences, and possible resolutions of EJ struggles.

Scale is deeply racialized, gendered, and classed. The impacts of climate change offer a telling example of how environmental racism reflects this fact. While the conclusions of climate scientists are remarkably clear that anthropogenic climate change is occurring at a dramatic pace and with increasing intensity, this is also happening unevenly, with people of color, the poor, indigenous peoples, peoples of 
the global South, and women suffering the most (Harlan et al., 2015). Thus, while climate change matters for all of us, it impacts people and nonhumans with different levels of intensity. If one only pays attention to the global scale, it appears that the worst effects of climate change are not yet upon us. But if one examines what is occurring in neighborhoods, barrios, indigenous peoples' lands, and much of the global South, the picture is quite different because the impacts are extensive and ongoing. As Keith Ellison and Van Jones (2015) put it, "[O]ur kids are being poisoned by the air they breathe. Environmental injustices are taking Black livesthat's why our fight for equality has to include climate and environmental justice too."

Social cognition studies find that "implicit bias" among White research subjects results in perceiving threats to their wellbeing when they see Black and Brown people when no such threat exists (Kang 2005). While this research is highly consequential for everyday microsociological interactions across the racial spectrum (especially in the case of gun violence in the name of White "self defense"), it has major macrosociological implications as well. Therefore I find that implicit bias is useful for thinking more deeply about the intersection of race and scale. In other words, if these studies find that people of color are implicitly viewed as threatening, then their presence is perceived to be much larger in the social-cognitive terrain of Whites.

Thus race and scale intertwine to reveal also that when Black people respond to racism (whether by police or via environmental racism), their actions may be viewed as a threat that is disproportionate and outsized. We can see this, for example, in the militarized response by police departments when interacting with the Black Lives Matter movement. Many supporters of the Black Lives Matter movement, and even military veterans, decried these practices when disturbing images of police and protesters clashing in Ferguson, Missouri, in response to the police killing of Michael Brown, seemed to be indistinguishable from media images of civilians being repressed by an occupying military force in some far away land. This fact begs for a scalar analysis that links militarized oppression of African Americans to the U.S. military's treatment of people of color elsewhere in the world-in Afghanistan, Iraq, Syria, Pakistan, Yemen, Palestine, and many other nations where the United States uses military force directly or by proxy to protect its interests. This is also an environmental justice issue because the U.S. military is one of the largest sources of pollution on earth (Nazaryan 2014) and because militarism and masculinist politics tend to go hand in hand and both tend to result in socially and ecologically harmful practices.

Finally, BLM's work speaks to the myriad ways that scale can be thought of and articulated temporally. In fact, the entire point of the BLM movement is, in some ways, an intervention to remind us that blatant acts of anti-Black violence are not a thing of the past and are still quite rampant in what some observers had hoped would be a "postracial" era. BLM co-founder Alicia Garza uses time as an indicator of the intersection of race, sexuality, and scale's intersections, but does so linking history to an imagined future:

But what I can say to my child, just like my mom says to me, is that there was a time when it wasn't OK for people to be out [about their sexuality]. There was a time when black people were being slaughtered. And I hope that the end to that story is, 'and then we organized, and we built a vibrant international movement, and we really changed conditions for black people in this country, and for everybody.' And I'm hoping that the story that I'm also able to tell is that our demands went beyond 'stop killing us,' to ensure the quality of life for everybody. And that we won that (Brydum 2015). 


\section{The Third Pillar: An Anti-Statist/Anarchist Reading of BLM}

Social inequalities - from racism to speciesism-are not aberrations, but rather are deeply embedded in society and reinforced by state power and market systems. Therefore, the current social order stands as a fundamental obstacle to social and environmental justice. A logical conclusion of this observation is that social change movements may be better off thinking and acting beyond the state and capital as targets of reform and/or as reliable partners.

Racism, for example, is a foundational component of the political, legal, economic, and cultural systems in the United States. African Americans, for instance, enjoy fewer rights and significantly lower social value than Whites, suffering deep economic, educational, public health, and environmental inequalities; earning far less income and owning far less wealth and property than Whites; and being more likely than Whites to attend low quality, segregated schools and live in residentially segregated communities marked by financial disinvestment, a brutal occupying police force presence, and environmental racism (Bullard 2000; Cacho 2012; Gilmore 2007; Vargas 2010). Public health disparities impact African Americans dramatically, as homicides, infant mortality, life expectancy, asthma, and a range of other illnesses and life events reveal a much lower statistical value of Black life (Williams and Collins, 1995). And millions of African Americans are either confined to prisons via mass incarceration or subjected to routine surveillance and control through the system of mass probation. Thus, racism is, for Black Lives Matter co-founder Alicia Garza, "a disease that this country has in our very DNA" (Garza 2015).

In a statement posted on the Black Lives Matter website, activists contend that the current state of racist violence against African Americans is a core component of American life, a form of oppression that Blacks have consistently challenged: "Rooted in the experiences of Black people in this country who actively resist our de-humanization, \#BlackLivesMatter is a call to action and a response to the virulent anti-Black racism that permeates our society" (BlackLivesMatter.com 2016).

Debates often center on whether social movements should seek to reform or transform the legal system. BLM is an important part of that conversation because it is a movement whose participants often embrace the state, but frequently do so in a critical fashion. For example, much of the chanting and protest calls at BLM events include demands to "prosecute the police" and implement stronger laws against hate crimes and police brutality (Furst 2016). ${ }^{1}$ The BLM's "National Demands" document reads, in part, "We will help develop a network of organizations and advocates to form a national policy specifically aimed at redressing the systemic pattern of anti-Black law enforcement violence in the U.S." (Moore and Cullors, 2014). In November 2015, after a group of White supremacists shot and wounded several activists who were protesting the police killing of an unarmed African American man named Jamar Clark in Minneapolis, BLM released a statement declaring, "The Black Lives Matter Network urgently calls upon the Department of Justice to investigate this shooting as a hate crime" (BlackLivesMatter.com 2015). Finally, BLM activists have regularly called for greater oversight over police and for increased presence of Black people in government decision-making bodies. For example, in the wake of numerous police killings of African Americans in recent years, the Los Angeles chapter of BLM demanded that the mayor appoint activists from the Black community to key city commissions, and a number of BLM activists are running for political office.

When BLM demands inclusion in governmental bodies and invokes the language of hate crimes and terrorism, such efforts may appear to reflect the power of grassroots movements to move state actors on important progressive issues, but it also indicates the movement's willingness to expand troubling, controlling, authoritative, and 
lethal state power. BLM is therefore not asking how we might build safe communities beyond the state, but rather how we might do so with greater state intervention. BLM co-founder Patrice Cullors' vision of social change includes a plan to "divest from policing and divest from this prison system . . . and reinvest into poor communities, reinvest into allowing us to have access to healthy food, access to jobs, access to shelter" (Cullors 2015).

From a pluralist perspective, states are sites where citizens and other stakeholders converge to elect representatives and make their voices heard and shape public policy (Dahl 2005). Departing from that view, a power elite perspective casts states as sites of power struggles, where certain interest groups tend to dominate others, setting public policy agendas and unevenly shaping life chances for members of society (Domhoff 2013). From Women of Color Feminist, Critical Race Theory, and Anarchist perspectives, states are also institutions that, by definition, practice exclusion, control, and violence (in addition to their other functions) (Goldberg 2002; Hong 2006; Mills 2001; Scott 2010; Smith 2011). Thus, the very purpose of a state is to exert dominance over populations, resources, and territory, among other things.

If Black Lives Matter was founded to challenge state-sanctioned violence then it makes sense to extend the reach of this movement's analysis and action to the problem of environmental racism. Since environmental racism is often a form of statesanctioned violence via the harm that state agencies and state-regulated companies perpetrate in communities of color, then BLM might do well to pay greater attention to this issue. If we think of environmental racism as a form of violent control over bodies, space, and knowledge systems then we can more effectively theorize it as a form of state violence, a framework that is absent from most EJ scholarship. ${ }^{2}$ Moreover, as some BLM activists urge us to think about how to make our communities safe "beyond policing" (Tometi 2015), both BLM and EJ activists and scholars might begin to think about how to make our communities sites of $\mathrm{EJ}$ and racial justice beyond the state. In fact, the BLM movement, the EJ movement, and EJ scholarship generally look to the state and its legal systems to deliver justice and to regulate industry. Thus far, however, the track record of state-based regulation and enforcement of racial and environmental justice policies in communities of color has been abysmal (Cole and Foster, 2000; Gilmore 2007; Lombardi et al., 2015).

\section{The Fourth Pillar: Indispensability}

Critical EJ Studies centers on the concepts of racial and socioecological indispensability. In Black and Brown Solidarity (2014), John Márquez introduces the concept "racial expendability" to argue that Black and Brown bodies are, in the eyes of the state and its constituent legal system, generally viewed as criminal, deficient, threatening, and deserving of violent discipline and even obliteration. Márquez and other ethnic studies scholars contend that, in a White supremacist society, people of color are constructed as and rendered expendable (Cacho 2012; Márquez 2014; Mills 2001; Vargas 2010). Ruth Wilson Gilmore speaks to this point in her book Golden Gulag (2007), in which she argues that the massive build up of prisons to warehouse people of color in the state of California and the United States nationally was a public policy decision designed to contain and control populations whose very existence is viewed as troubling. Extending this logic to the problem of environmental racism, philosopher and critical race theorist Charles Mills argues that people of African descent are considered "trash" by policy makers and institutions promoting discriminatory environmental policies because these populations are associated with filth, waste, and uncleanliness in the popular imagination-thus locating pollution in their communities actually makes cultural common sense (Mills 2001). 
Critical EJ Studies builds on the work of these scholars by countering the ideology of White supremacy and human dominionism and articulating the perspective that excluded, marginalized, and othered populations, beings, and things-both human and more-than-human-must be viewed not as expendable but rather as indispensable to our collective futures. This is what I term racial indispensability (when referring to people of color) and socioecological indispensability (when referring to broader communities within and across the human/more-than-human divide and their relationships to one another). Racial indispensability is intended to challenge the logic of racial expendability and is the idea that institutions, policies, and practices that support and perpetrate anti-Black racism suffer from the flawed assumption that the future of African Americans is somehow de-linked from the future of White communities. People of color are members of our society, are core participants in our social systems, and are members of our socioecological systems, and are therefore key to ensuring the continued functioning, sustainability, and resilience of our society and planet.

The idea of indispensability is distinct from an assimilationist perspective, which seeks to (often involuntarily and violently) incorporate "others" into one's own vision of a society (Smith 2005). Rather, indispensability honors key EJ and ecological principles by seeing all communities (more-than-human and human) as interconnected, interdependent, but also sovereign and requiring the solidarity of others. Indispensability should also not be confused with a Functionalist view of society and socioecological relations as it recognizes that social roles, positions, and behaviors among various populations can and do conflict and change over time, and that the character of inequality and state and market power in most societies is highly unjust and must be confronted. Functionalism, on the other hand, posits that whatever the character of inequality, social roles, and behaviors may be, it must be positive for society and therefore is in no need of change (Parsons 1954). Indispensability argues against that logic because CEJ Studies is fundamentally focused on securing justice and sustainability in a highly unjust and unsustainable system. Thus indispensability demands dramatic change but does so from the perspective that all members of society and socioecological systems have something to contribute to that process and to our collective futures.

Socially, politically, philosophically, and ecologically, what this means is that we are all linked in webs of social interdependence, so that what happens to one group affects, in some way, all others. As Dr. Martin Luther King, Jr. famously wrote in his landmark "Letter from Birmingham Jail" with regard to racism and the future of the United States: "Injustice anywhere is injustice everywhere. . . In a real sense all life is inter-related. All men are caught in an inescapable network of mutuality, tied in a single garment of destiny. Whatever affects one directly, affects all indirectly. Never again can we afford to live with the narrow, provincial 'outside agitator' idea ...” (King 1963).

Thus the importance of CEJ studies here is to underscore that social systems predicated on the annihilation of Black life reveal a self-defeating error. In other words, the idea that Whiteness can only triumph and survive via the annihilation of Black life commits the classic ecological error of dualism or separation. Dualism is the idea that we see various categories of existence as separate and arranged in oppositional hierarchies, such as culture/nature, man/woman, European/non-European, human/animal, White/Black, heterosexual/homosexual, etc., when in fact these categories are constantly blurred, transgressed, and revealed to be socially constructed and highly fluid and malleable. So CEJ Studies facilitates an understanding that a vision of White supremacy premised on the destruction of people of color is as illogical and self-defeating as a vision of an economy and a nation-state premised on the destruction of ecosystems. In a sense, this observation demonstrates a reality of social systems as ecosystems, and vice versa: that everything in the universe is hitched to everything 
else, so that what affects one member or element affects all of them. The destruction of people of color harms White people and it harms the more-than-human world, and vice versa, so CEJ Studies affirms that Black lives, the lives of people of color, are indispensable. Going further, the idea of socioecological indispensability reflects the CEJ Studies perspective that the wellbeing of all people, species, and ecosystems is indispensible. This is both a socioecological reality and an affirmation of a politics of solidarity and coalition building that firmly states "All of us or none!"

Black Lives Matter activists routinely speak to this issue as well. In 2015, BLM issued a "State of the Black Union" in which they wrote, "None of us are free until all of us are free" (DeclarationProject.org 2015). This is a variation on a quote that has been attributed to the likes of the poet Emma Lazarus, the Reverend Dr. Martin Luther King, Jr., and many others. It is also articulated powerfully in the Barry Mann song "None of Us Are Free," which includes the chorus, "None of us are free, none of us are free, if one of us is chained, none of us are free."

Expressing this view more than a century ago, African American historian Anna Julia Cooper told a group of Black clergymen in 1892, "Only the Black woman can say 'when and where I enter, in the quiet, undisputed dignity of my womanhood, without violence and without suing or special patronage, then and there the whole . . race enters with me"' (Bailey 2004, p. 56). A year later, making this claim even stronger, at the 1893 World's Congress of Representative Women, Cooper stated:

Let woman's claim be as broad in the concrete as the abstract. We take our stand on the solidarity of humanity, the oneness of life, and the unnaturalness and injustice of all special favoritism, whether of sex, race, country, or condition. If one link of the chain is broken, the chain is broken. A bridge is no stronger than its weakest part, and a cause is not worthier than its weakest element. Least of all can woman's cause afford to decry the weak. We want, then, as toilers for the universal triumph of justice and human rights, to go to our homes from this Congress demanding an entrance not through a gateway for ourselves, our race, our sex, or our sect, but a grand highway for humanity (Cooper 1892).

BLM co-founder Alicia Garza echoes and articulates this idea as follows:

\#BlackLivesMatter doesn't mean your life isn't important-it means that Black lives, which are seen as without value within White supremacy, are important to your liberation. Given the disproportionate impact state violence has on Black lives, we understand that when Black people in this country get free, the benefits will be wide reaching and transformative for society as a whole. When we are able to end hyper-criminalization and sexualization of Black people and end the poverty, control, and surveillance of Black people, every single person in this world has a better shot at getting and staying free. When Black people get free, everybody gets free. This is why we call on Black people and our allies to take up the call that Black lives matter. ... Our collective futures depend on it (Garza 2014, emphasis added).

\section{DISCUSSION AND CONCLUSION}

Critical Environmental Justice Studies seeks to expand the field of EJ Studies to move beyond its conceptual, theoretical, disciplinary, and methodological limitations. Since that path is still very much in formation, this paper is an effort to chart one course in that direction with greater specificity. Critical EJ Studies draws from numerous fields 
of scholarship in order to produce more robust accounts for why environmental injustices occur and persist, for how human and nonhuman forces shape and are shaped by them, and for what environmental justice might look like. That is, the promise of CEJ Studies lies in its capacity to more fully explain the sources and consequences of our socioecological crises and develop more generative analyses of how social change efforts within and across species may meet those challenges.

Finally, CEJ Studies can aid scholars and advocates in thinking through a redefinition of the concept of environmental justice itself. Perhaps any discussion regarding the future of EJ Studies and the EJ movement might begin by connecting early EJ scholarship, which centers primarily around the intersection of social inequality and environmental harm, with the concept of ecological justice, which centers on the relationship of human beings to the broader nonhuman world. By the term ecological justice, I mean to suggest a more respectful and egalitarian relationship of human beings to one another and to the greater more-than-human world. This model of analysis and politics begins with humans taking responsibility for practicing transformative socioecological political work and extends to understanding inequalities within and across species and space to imagine and struggle for a more democratic multispecies world. Nonhuman species and ecosystems may not engage in politics the way humans tend to, but they can and do exert influence and power over the world (Bennett 2009): for example, consider the impacts of fossil fuels on the daily lives of human beings and on the political systems and economies of every nation on Earth. Ecological justice destabilizes the notion of the human as a biological category at the apex of a human/nature hierarchy and, instead, embraces it as a political category that engages with the broader ecological community. This model of politics also rejects the state as an arbiter of justice and inclusion. The state has managed, included, excluded, homogenized, and controlled humans and nonhuman natures for the benefit of a small elite. That should be reason enough to consider the merits of an anarchist or anti-authoritarian approach to socioecological change. Curiously, this concept of ecological justice closely mirrors and parallels the Principles of Environmental Justice - a sort of founding document of the U.S. EJ movement, suggesting that, in many ways, the EJ movement and EJ Studies have yet to catch up to the vision of the movement's founding principles, which are largely aligned with a CEJ Studies perspective.

In this paper, I applied a Critical Environmental Justice perspective to the phenomenon of the Black Lives Matter movement, demonstrating how attention to multiple categories of difference and inequality (including more-than-human species and the built environment); an emphasis on the role of scale as a way of understanding the violence of racism and the promise of resistance movements; a focus on linking the entrenched character of social inequalities with transformative, anti-authoritarian and anarchist perspectives; and an application of the concepts of racial and socioecological indispensability can produce an enriched account of that movement's core concerns, its limitations, and its possibilities. Black Lives Matter challenges the scourge of statesanctioned violence against diversely constituted communities of African descent, with a primary emphasis on police brutality and mass incarceration. I argue that if we think of environmental racism as an extension of those state-sanctioned practices-in other words a form of authoritarian control over bodies, space, and knowledge systemsthen we can more effectively theorize it as a form of state violence, a framework that is absent from most EJ scholarship.

Corresponding author: David N. Pellow, Environmental Studies Program, University of California Santa Barbara, 4312 Bren Hall, Santa Barbara, CA 93106-4160. E-mail: pellow@es.ucsb.edu 


\section{NOTES}

1. After the November 2015 police killing of Jamar Clark, an unarmed African American male in Minneapolis, Minnesota, Black Lives Matter protesters demanded that the state prosecute the officers involved. The state declined to do so.

2. For exceptions, see, e.g., Liam Downey (2015) and Andrea Smith (2005).

\section{REFERENCES}

Adams, Carol J. (2010). The Sexual Politics of Meat: A Feminist-vegetarian Critical Theory. London: Bloomsbury Academic.

Adamson, Joni (2011). Medicine Food: Critical Environmental Justice Studies, Native North American Literature, and the Movement for Food Sovereignty. Environmental Fustice, 4(4): 213-219.

Agyeman, Julian, Peter Cole, Randy Haluza-DeLay, and Pat O'Riley (Eds). (2010). Speaking for Ourselves: Environmental fustice in Canada. Seattle, WA: University of Washington Press.

Ascione, Frank (1997). Battered Women's Reports of Their Partners' and Their Children's Cruelty to Animals. Fournal of Emotional Abuse, 1(1): 119-133.

Bailey, Cathryn (2004). Anna Julia Cooper: 'Dedicated in the Name of My Slave Mother to the Education of Colored Working People.' Hypatia, 19(2): 56-73.

Bell, Shannon Elizabeth (2013). Our Roots Run Deep as Ironweed: Appalachian Women and the Fight for Environmental Fustice. Champaign, IL: University of Illinois Press.

Bennett, Jane (2009). Vibrant Matter: A Political Ecology of Things. Durham, NC: Duke University Press.

Bijan, Stephen (2015). Social Media Helps Black Lives Matter Fight the Power. Wired, November 2015. <http://www.wired.com/2015/10/how-black-lives-matter-uses-social-media-to-fightthe-power/> (accessed June 2, 2016).

BlackLivesMatter.com (2016). All \#BlackLivesMatter: This is Not a Moment, but a Movement. $<$ http://www.blacklivesmatter.com/about> (accessed June 23, 2016).

BlackLivesMatter.com (2015). DOJ: Protect Black Activists from White Vigilante Violence. <https://www.facebook.com/BlackLivesMatter/posts/513206922183891> (accessed June 23, 2016).

Brydum, Sunnivie (2015). Alicia Garza Taking Black Lives Matter into Another Dimension. The Advocate, December 9. < http://www.advocate.com/40-under-40/2015/12/09/alicia-garzataking-black-lives-matter-another-dimension> (accessed June 2, 2016).

Buckingham, Susan and Rakibe Kulcur (2010). Gendered Geographies of Environmental Justice. In Ryan Holifield, Michael Porter, and Gordon Walker (Eds.), Spaces of Environmental fustice, pp. 70-94. New York: Wiley-Blackwell.

Bullard, Robert D. (2000). Dumping in Dixie: Race, Class, and Environmental Quality. Boulder, CO: Westview Press.

Cacho, Lisa (2012). Social Death: Racialized Rightlessness and the Criminalization of the Unprotected. New York: New York University Press.

Change.org (2015). Terminate Officer Jennifer Lynne Silver. Online petition to Baltimore Mayor Stephanie Rawlings-Blake. April. <https://www.change.org/p/mayor-stephanierawlings-blake-commissioner-anthony-batts-captain-douglas-irwin-terminate-officerjennifer-lynne-silver> (accessed June 23, 2016).

Cole, Luke and Sheila Foster (2000). From the Ground Up: Environmental Racism and the Rise of the Environmental fustice Movement. New York: New York University Press.

Collins, Patricia Hill (2008). Black Feminist Thougbt. New York: Routledge.

Cooper, Ana Julia (1892). A Voice from the South. New York: Aldine Printing.

Cullors, Patrisse (2015). Interview on Democracy Now! July 24. <http://www.democracynow. org/2015/7/24/part_2_blacklivesmatter_founders_on_immigration> (accessed June 2, 2016).

Dahl, Robert (2005). Who Governs? Democracy and Power in an American City. New Haven, CT: Yale University Press.

DeclarationProject.org (2015). State of the Black Union. January 22. <http://www.declarationproject.org/? $\mathrm{p}=1654>$ (accessed June 23, 2016).

Domhoff, G. William (2013). Who Rules America? The Triumph of the Corporate Rich. New York: McGraw-Hill Education

Downey, Liam (2015). Inequality, Democracy and the Environment. New York: New York University Press. 
Ellison, Keith and Van Jones (2015). Pollution Isn't Colorblind. The Guardian, July 24. <http://www.theguardian.com/commentisfree/2015/jul/23/black-lives-matter-air-pollution> (accessed June 2, 2016).

Fantz, Ashley, George Howell, and Catherine Shoichet (2014). Gunshots, Tear Gas in Missouri Town Where Police Shot Teen. CNN.com, August 12. <http://www.cnn.com/2014/08/11/ us/missouri-teen-shooting/> (accessed June 2, 2016).

Friedersdorf, Conor (2015). The Brutality of Police Culture in Baltimore. The Atlantic, April 22. <http://www.theatlantic.com/politics/archive/2015/04/the-brutality-of-police-culture-inbaltimore/391158/> (accessed June 2, 2016).

Furst, Randy (2016). Protesters Demand Prosecution of Officers Involved in Jamar Clark Shooting. Minneapolis Star Tribune, February 12. <http://m.startribune.com/protestersdemand-prosecution-of-officers-involved-in-jamar-clark-shooting/368675951/> (accessed June 22, 2016).

Gaard, Greta (2004). Toward a Queer Ecofeminism. In Rachel Stein (Ed.), New Perspectives on Environmental fustice, pp. 21-44. New Brunswick, NJ: Rutgers University Press.

Garza, Alicia (2014). A Herstory of the \#BlackLivesMatter Movement. The Feminist Wire, December 6. <http://www.thefeministwire.com/2014/10/blacklivesmatter-2/> (accessed June 2, 2016).

Garza, Alicia (2015). Interview on Democracy Now! July 24. <http://www.democracynow. org/2015/7/24/part_2_blacklivesmatter_founders_on_immigration> (accessed June 2, 2016).

Gilmore, Ruth Wilson (2007). Golden Gulag: Prisons, Surplus, Crisis, and Opposition in Globalizing California. Berkeley, CA: University of California Press.

Goldberg, David Theo (2002). The Racial State. Oxford, UK: Blackwell Publishers.

Griswold, Alex (2015). CNN Guest: Black Men 'Hunted Down Like Deer and Like Dogs.' The Daily Caller, April 14. <http://dailycaller.com/2015/04/14/cnn-guest-black-men-in-americahunted-down-like-deer-and-like-dogs-video/> (accessed June 2, 2016).

Harlan, Sharon, David N. Pellow, and J. Timmons Roberts, with Shannon Elizabeth Bell, William G. Holt, and Joane Nagel (2015). Climate Justice and Inequality. In Riley Dunlap and Robert J. Brulle (Eds.), Climate Change and Society: Sociological Perspectives, pp. 127-163. Oxford, UK: Oxford University Press.

Herod, Andrew (2011). Scale. London: Routledge.

Holifield, Ryan, Michael Porter, and Gordon Walker (2010). Introduction-Spaces of Environmental Justice-Frameworks for Critical Engagement. In Ryan Holifield, Michael Porter, and Gordon Walker (Eds.), Spaces of Environmental fustice, pp. 1-22. Oxford, UK: Wiley-Blackwell.

Hong, Grace Kyungwon Hong (2006). Ruptures of American Capital: Women of Color Feminism and the Culture of Immigrant Labor. Minneapolis, MN: University of Minnesota Press.

Kang, Jerry (2005). Trojan Horses of Race. Harvard Law Review, 118: 1489-1593.

King, Martin Luther, Jr. (1963). Letter from Birmingham Jail. <https://www.africa.upenn. edu/Articles_Gen/Letter_Birmingham.html> (accessed August 5, 2016).

Lombardi, Kristen, Talia Buford, and Ronnie Greene (2015). Environmental Justice, Denied. Center for Public Integrity. August 3. <https://www.publicintegrity.org/environment/ environmental-justice-denied $>$ (accessed March 1, 2016).

Márquez, John (2014). Black-Brown Solidarity. Austin, TX: University of Texas Press.

Mills, Charles (2001). Black Trash. In Laura Westra and Bill E. Lawson (Eds.), Faces of Environmental Racism, pp. 73-93. Lanham, MD: Rowman \& Littlefield.

Moore, Darnell and Patrisse Cullors (2014). 5 Ways to Never Forget Ferguson-And Deliver Real Justice for Michael Brown. The Guardian.com, September 4. < https://www.theguardian. com/commentisfree/2014/sep/04/never-forget-ferguson-justice-for-michael-brown> (accessed on June 22, 2016).

Morris, Aldon (1984). Origins of the Civil Rights Movement. New York: Free Press.

Nazaryan, Alexander (2014). The U.S. Department of Defense is one of the World's Biggest Polluters. Newsweek, July 17. <http://www.newsweek.com/2014/07/25/us-department-defenceone-worlds-biggest-polluters-259456.html> (accessed March 1, 2016).

Nibert, David and Michael W. Fox (2002). Animal Rights/Human Rights. Lanham, MD: Rowman and Littlefield.

Nichols, Jason (2015). Black Baltimore Residents Aren't 'Animals.' We Punish People for Killing 'Animals.' The Guardian, April 28. http://www.theguardian.com/commentisfree/2015/ apr/28/black-baltimore-residents-arent-animals-we-punish-people-for-killing-animals> (accessed June 2, 2016).

Parsons, Talcott (1954). Essays in Sociological Theory. New York: The Free Press. 


\section{David N. Pellow}

Pellow, David N. (2007). Resisting Global Toxics. Cambridge, MA: The MIT Press.

Pellow, David N. and Robert J. Brulle (Eds.) (2005). Power, Fustice, and the Environment. Cambridge, MA: The MIT Press.

Pulido, Laura (1996). A Critical Review of the Methodology of Environmental Racism Research. Antipode, 28(2): 142-159.

Ringquist, E. J. (2005). Assessing Evidence of Environmental Inequities. Fournal of Policy Analysis and Management, 24(2): 223-247.

Roberts, J. Timmons and Bradley Parks (2006). A Climate of Injustice. Cambridge, MA: The MIT Press.

Scott, James (2010). The Art of Not Being Governed. New Haven, CT: Yale University Press.

Smith, Andrea (2005). Conquest: Sexual Violence and American Indian Genocide. Boston, MA: South End Press.

Smith, Mick (2011). Against Ecological Sovereignty. Minneapolis, MN: University of Minnesota Press.

Smits, David (1994). The Frontier Army and the Destruction of the Buffalo: 1865-1883. The Western Historical Quarterly, 25(3): 312-338.

Sze, Julie (2006). Boundaries and Border Wars: DES, Technology, and Environmental Justice. American Quarterly, 58(3) 791-814.

Sze, Julie (2016). Scale. In Joni Adamson, William Gleason, and David N. Pellow (Eds.), Keywords for Environmental Studies, pp. 178-180. New York: New York University Press.

Tometi, Opal (2015). Interview on Democracy Now! July 24. <http://www.democracynow. org/2015/7/24/part_2_blacklivesmatter_founders_on_immigration> (accessed June 2, 2016).

Vargas, Joao H. Costa (2010). Never Meant to Survive: Genocide and Utopias in Black Diaspora Communities. Lanham, MD: Rowman \& Littlefield.

Walker, Gordon (2010). Beyond Distribution and Proximity: Exploring the Multiple Spatialities of Environmental Justice. In Ryan Holifield, Michael Porter, and Gordon Walker (Eds.), Spaces of Environmental fustice, pp. 24-46. Oxford, UK: Wiley-Blackwell.

Williams, David R. and Chiquita Collins (1995). U.S. Socioeconomic and Racial Differences in Health: Patterns and Explanations. Annual Review of Sociology, 21: 349-86. 